\title{
LOCAL WISDOM OF DESA GADANG VILLAGE OF KAMPAR REGENCY IN AN EFFORT TO IMPROVE TOURISM POTENCY OF RIAU PROVINCE
}

\author{
Geovani Meiwanda
}

\author{
Lecturer of Public Administration \\ Universitas Riau \\ geovani.meiwanda@lecturer.unri.ac.id
}

\begin{abstract}
The village of Pulau Gadang District XII Koto Kampar, Kampar regency is a village that has an interesting historical value. Starting from the transfer of old Gadang Island Village to the current area due to the Koto Panjang PLTA Project, drowning four villages including Pulau Gadang Village. After 25 years passed the transfer was successful to give a positive impact, although initially received rejection. Improving the economy of local communities, supported by the tourism potential that recently developed in the area of this village and directly managed by the community of Pulau Gadang Village. Tourist attraction that is currently viral enough that Raja Ampat his Riau, at the beginning of the emergence of a very loved but the highest point of achievement only up there only. Tourism sector is a leading sector that is being developed and managed directly by the surrounding community, of course the positive impact of increasing the tourism potential in Riau. this paper will provide an in-depth analysis of the local wisdom of the community of Pulau Gadang Village that manages tourism directly, based on the construction of the concept of local wisdom that is capable of bringing progress to a region. Local wisdom is now an interesting issue as it returns to the foundation of a development theory that post modernism that can succeed a region is when the specialty of the area can be managed properly. Local wisdom that has influence in attitude and action, local local ideas that are wise, full of wisdom, good value, embedded and followed by members of the community.
\end{abstract}

Key Words: Local Wisdom, Local Government and Tourism

\section{Introduction}

Local wisdom is an integrated way in the social life of the community, specifically the village community. The intermingling between the way and outlook of the community towards something mixed with village governance makes local wisdom a policy. Wisdom is present, of course when the present propositions between local wisdom and village government are balanced, wisdom is present when there is a common perception to build between the village government and traditional leaders. Along with the development of science in the perspective of public administration, issues that raise local wisdom are considered attractive to be appointed. The debate about the presence of local wisdom for development is also diverse, because the socio-cultural dynamics that exist in Indonesia are rich.

Local wisdom that is present is able to penetrate a variety of perspectives in community life such as the environment, disaster management, land, agriculture, plantations including the current sector which is very rapidly developing namely tourism. The level of success varies even though wisdom in local wisdom is present to accompany village government.

The Village Law Perspective Number 6 of 2014 gives the village the authority to manage all the potential possessed by a village, but it cannot be denied the current problem dilemma is not all villages are able to manage their own potential. The special budget allocated for village government is not able 
to be explored more deeply for some villages but in some villages collaborating with the village administration with local wisdom is considered a good way to explore the potential of a village.

Subdistrict XII Koto Kampar is a sub-district that has a village with unique historical value, one of which is Pulau Gadang Village. Pulau Gadang Village is a new village. Pulau Gadang Village is located in District XIII Koto Kampar, Kampar Regency, Riau Province. Village with an area of 12,863.5 Ha. The east is bordered by the village of Koto Mesjid and the west borders the villages of Lubuk Agung and Tanjung Alai. Whereas in the south bordering Balung Village and next to the north bordering the Kabun and Batu Langka areas. Pulau Gadang Village is a division of Koto Masjid Village, XII Subdistrict, Koto Kampar.

The former Pulau Gadang village was located in the Koto Panjang Hydroelectric Reservoir area, but with the construction of the reservoir the village was drowned and then moved to a new area. Around 4000 families were moved, and the government did and gave compensation in 1992. Currently in 2018 it has been 26 years since the people of Desa Gadang settled in a new place and have their livelihoods. Kampar Regency has customary norms and customs that are quite interesting to trace and the community is still very close to traditional norms, the lineage is taken almost the same as the Minang Kabau culture, namely from mother or matrilineal.

Still high in upholding adat, it will certainly influence the management of the rhythm of rural development, by building the potential of Gadang Island, District XII Koto Panjang, Kampar Regency. Currently tourism is a leading sector that has been glimpsed in almost all regions in Riau, and does not miss the momentem of Gadang Island. Since 2017 Pulau Gadang Village, Kampar District has been neutralized by posting pictures with the headline "Raja Ampat KW" or "Raja Ampat Riau". The strategic location in the ring road between Riau Province and West Sumatra Province makes the Raja Ampat Riau version always crowded.

This Tourism Potential has become an interesting object, the islands that were inundated by the Koto Panjang PLTA reservoir water were added with historical stories where under the water the reservoir was once a submerged village. This potential is managed directly by the local community, in a traditional way. Customary leaders, tourism conscious groups, village administrations and provinces also look to make improvements so that the existence of this potential can last long not only be a seasonal tourist attraction.

Direct management by the community, both from working on locations, arranging fees for entry until the food being sold indicates that local wisdom is implicit there, even though the village head from Pulau Gadang Village said the village government plays a dominant role in it. Talking about local wisdom will always intersect with how society behaves with an indigenous perspective. Customary land, or joint property that is not actually for sale, began to disappear because many investors from outside the city bought the land because they knew the potential of the village with a viral view of Riau's Raja Ampat.

The loss of ulayat land will trigger the erosion of local wisdom in managing the tourism potential, as if privatization dominates in the end in managing the potential of Pulau Gadang Village which should have local wisdom as at the beginning when starting and discovering the tourism potential. The phenomenon of tourism will increasingly have value if it collaborates with the culture of its people, which hopes that the challenge of tourism capitalists will not minimize the movement of local local wisdom.

\section{Local Wisdom}

Local wisdom can not be separated from certain values and norms is the result of adaptation and life experience of a community group in a particular location which then gives a certain form of thought patterns and actions as a way to live in harmony with their environment, with each other, and with themselves (Djajadi , 2014) Local wisdom can be tangible (textual, architectural, traditional artwork) and intangible (system of values, songs, advice), and in terms of types of local wisdom consists of 
governance, value systems, procedures, and special provisions such as sensitive areas and regions / holy building (Darmawan, 2010).

According to Walker (1996), the incorporation (incorporation) of local wisdom into tourism development can provide benefits in the economic, physical, and socio-cultural fields at local locations. The explanation is

1. Economy, including the availability of employment opportunities, the creation of a variety of employment opportunities, as well as increasing the income of residents and regions;

2. Environmental physics, including maintaining historical buildings and cultural / natural heritage, creating infrastructure improvements, increasing efforts to conserve flora and fauna and their ecosystems;

3. Socio-culture, among others, is a question of efforts to safeguard local cultural values, increase citizens' pride, increase opportunities for higher education, and help citizens understand themselves (who, where, and uniqueness they have).

Local Wisdom Approach in Tourism Development based on local wisdom (Sastrayuda, 2010):

1. Participatory planning, involving all theoretical and practical elements in planning and developing the sustainability of tourist areas

2. Potential and availability characteristics of cultural products that can support the sustainability of tourism management

3. Community empowerment approach, by providing opportunities for the surrounding community to develop personal and group abilities

4. Regional approach, by looking at the linkages of the surrounding regions to see the potential and planned in a balanced manner

5. Optimization approach to potential that can be integrated, taking into account the cultural and tourism potential that can be integrated.

Selain itu, terdapat dua pendekatan dasar dalam melakukan gabungan kearifan lokal dalam pengembangan pariwisata (Walker, 1996), yaitu

1. Buying product, dengan memasuk-kan unsur kearifan lokal dalam produk wisata yang dapat dinikmati seperti suvenir dan kuliner.

2. Buying experience, dengan menggabungkan unsur kearifan lokal dalam kegiatan yang dapat memberikan pengalaman langsung kepada wisatawan.

\section{Research Method}

This research uses a qualitative approach, has research stages that go beyond various stages of scientific critical thinking, in which a researcher begins to think inductively that is capturing various facts or social phenomena through observations in the field, then analyzing and trying to do theorization based on what is observed . Researchers objectively conduct research on the problems of the research they want to study. Qualitative approaches are carried out through in-depth interviews (indept interviews) and FGDs to informants taken by purposive sampling of informants who are considered capable of answering and helping researchers to conduct analysis in this study.

\section{Discussion}

Local wisdom in the development of tourism is certainly not separated from every stage that must be side by side in that policy. Identification of available resources will be the first step as capital owned, with historical capital from the Koto Panjang Hydroelectric Power Plant and Jalan Pulau formed from areas that are drowned into initial resources, including customs that have been present so far. Potential as the next step that must be owned and able to be mapped in a tourism development of Koto Panjang Hydroelectric Power Plant which is Raja Ampat Riau, has the potential to be strategically located so as to facilitate promotion to the current viral especially in West Sumatra and Riau. 
Identification of resources and potential have indeed been known by the people of Pulau Gadang Village, but only limited to the management of making a place to combine the concept of wealth from local wisdom. A number of traditional prayer leaders from the Malay tribe (Datuak) explained that quite a number of lands were sold by the Head of the Tribe, which was not justified. The tourism capitalists who are present are not local wisdom, local wisdom is only present at the potential stage but continued by the next source. There are no plans for development or innovation in the existing potential, it can be done by utilizing local wisdom.

This potential will certainly achieve two major targets, namely the development that will reach Pulau Gadang Village, then the community economy will also spin. It is the community that has great potential to be able to directly manage this potential. At present the community has also been involved, plus the existence of a Tourism Awareness Group (Pokdarwisa), but of course this is not perfect and if the concern is that Raja Ampat Riau is only able to survive not in the long term, or just become a seasonal tourist attraction .

Basically, residents who live around the Koto Panjang Reservoir are residents and descendants of residents who come from villages that have been drowned due to the construction of the reservoir so that the existence of the reservoir has become part of the life of the local community. The construction of this reservoir was one of the results of the national economic policy in 1970. Construction of the reservoir drowned 10 villages consisting of 8 villages in Riau Province and 2 nagari (villages) in West Sumatra Province. The two villages that were drowned were Tanjuang Balik and Tanjuang Pauah, while the eight villages that were sunk were Muara Mahat Village, Tanjung Alai Village, Batu Bersurat Village, Pulau Gadang Village, Pongkai Village, MuaraTakus Village, Gunung Bungsu Village, and Koto Tuo Village. One of the drowned villages is believed to keep a history of Muara Takus Temple which is located not far from the reservoir area. Muara Takus Temple itself is one of the historical attractions in Kampar Regency. This temple is located west of the reservoir, precisely on the banks of the Kampar River. The history of the original location of the submerged village also needs to be preserved.

The community around the reservoir has a routine culture every year, namely Balimau Kasai. Balimau Kasai is a traditional effort carried out to welcome the month of Ramadan. Upara is conducted a day before entering Ramadan. This ceremony is carried out as an expression of gratitude for the coming of the fasting month and as a symbol of purification before entering the fasting month. Balimau means bathing using water mixed with orange peanuts. Kasai is a perfume used for shampooing.

In addition to traditional ceremonies, the behavior and habits of the gardening community can be a special attraction in the development of tourism activities in the Koto Panjang Reservoir. Communities around the reservoir also have musical arts such as Calempong music and gubano dhikr which are often used in traditional activities. Not only facilitates tourists with tourism objects but also with the people of Pulau Gadang Village itself, a variety of history ranging from the history of Muara Takus that falls under the lake, the history of the Koto Panjang Hydroelectric Power Plant, then how the customs of the Kampar community include food and Kmapar typical snacks that can be displayed.

The elements of the area are highly prioritized so that visitors can feel the complete atmosphere if visiting Raja Ampat Riau in Pulau Gadang Village, not just taking pictures from the top tourist spots. Cultural attractions that can be optimized for the everyday language of the Kampar language. Socioculture is an aspect that can directly and only be presented by the surrounding community.

The approach that can be taken in developing Pulau Gadang Village tourism by combining local wisdom can be combined with several approaches, namely:

a. Participatory Plan-ning approach

The socio-cultural sustainable conditions are represented by the guideline of the value of harmony with fellow human beings in this regard are stakeholders and tourists. Then, in terms of economic sustainability, the concept of development will be directed to encourage the growth of economic activities of local communities. How customary norms apply, unique attitudes and dress can be highlighted as supporters. 
b. Potential and Characteristic Approaches

This approach will be divided into two sub approaches, namely an approach that combines buying products and buying experience. buying product will be realized by selling tourist products in the form of traditional art products with basic ingredients that are environmentally friendly. buying experience is realized by procuring types of seascapes and landscape designs by utilizing the potential of local wisdom and the potential of marine tourism. In this case, it is more focused on how to provide experience to tourists to feel Raja Ampat Riau as well as local wisdom.

\section{Conclusion}

The local wisdom approach in the development of sustainable marine tourism in the Raja Ampat Riau tourist area is carried out in two outline approaches, namely the participatory planning approach and the potential approach and characteristics of cultural products combined with the approach of buying product and buying experience. From each of the existing approaches, local wisdom into the development of sustainable maritime tourism is realized in the form of drafting the concept of regional development and structuring based on the value system of local wisdom, selling tourism products.

\section{Bibliography}

Butler, R.W. (1980). The concept of tourism area cycle of evolution : implications for the management of resources. Canadian Geographer: University of Western Ontario.

Djajadi, I. (2010). Kearifan ilmiah \& kearifan lokal: pedoman bagi perumusan kearifan lokal Kalbar. Kongres Kebudayaan Kalimantan Barat II

Erickson, V. A. (2001). A research paper submitted in partial fulfillment for the masters of science degree with a major in hospitality and tourism. the graduate college university of wisconsin-stout. heritage tourism : a case study of the laura ingalls wilder heritage tourism site at pepin. university of wisconsin: wisconsin.

Taramatika, Fenilia. Inkorporasi Kearifan Lokal Dalam Pengembangan Kawasan Pariwisata Di Lingkungan Pantai. Itb; Bandung

Walker, L. and Diana B. (1996). The Tourism action society in the kootenays : step by step guide to heritage tourism development in the kootenay-Boundary. Kootenay. 